\title{
Osmotolerant Rhizobacteria Improve Seedling Vigour and Plant Growth of Mustard under Water Scarcity
}

\author{
N. Nivetha, A. Kiruthika, Arambam Devi Asha, A. K. Lavanya, \\ K. V. Vikram, B. S. Manjunatha and Sangeeta Paul* \\ Division of Microbiology, ICAR-IARI, New Delhi, India \\ *Corresponding author
}

\begin{tabular}{l} 
Ke y w o r d s \\
$\begin{array}{l}\text { Osmotolerance, } \\
\text { Mustard, } \\
\text { Germination, Plant } \\
\text { growth, Water } \\
\text { deficit stress }\end{array}$ \\
\hline Article Info \\
\hline $\begin{array}{l}\text { Accepted: } \\
\text { 14 November } 2020 \\
\text { Available Online: } \\
\text { 10 December } 2020\end{array}$ \\
\hline
\end{tabular}

\section{A B S T R A C T}

\section{Introduction}

Drought is an extreme climate event that develops slowly followed by increase in intensity and duration which leads to major eco-hydrological and socio-economic impacts (Kim et al., 2019). Drought is expected to become more severe and common in the coming decades as a result of global warming. Indian agriculture heavily relies on country's climate. Failure in monsoons leads to water shortage and reduction in crop growth and production. Extreme stress conditions limit plant growth and development. All stages of plant growth were affected by drought (Fahad et al., 2014). Drought stress reduces seed 
germination and plant development by influencing various physiological and biochemical functions of plants.

Mustard is one of the most important oilseed crops in the world and especially in India, primarily grown as an edible oil seed crop. The oil content of mustard seeds varies from $28.6 \%$ to $45.7 \%$. Seed residue after oil extraction is used as cattle feed and fertilizer ((Jensen et al., 1996). Nearly $37 \%$ of the total rapeseed mustard area is rain-fed in India, where the crop is prone to be affected by drought which results in acute yield losses. All stages of plant growth were affected by drought stress including seed germination, early stages of germination, vegetative and reproductive stages of mustard (Ghobadi et $a l ., 2006)$. Reduction in plant height, number of primary branches and secondary branches per plant, thousand seed weight and seed yield were observed as a result of drought stress in mustard. Under drought condition, yield reductions of 17-94 \% have been reported in mustard (Chauhan et al., 2007).

Recent studies indicate that microorganisms can also help the crops to cope with drought stresses which are an eco-friendly and costeffective method. Meena et al., (2017), reported that bacteria belonging to different genera including Bacillus, Pseudomonas, Rhizobium, Paenibacillus, Burkholderia, Achromobacter, Azospirillum, Enterobacter, etc. have been reported to provide tolerance to host plants and also improve their growth under drought. Enhancement in germination of seeds, growth of seedlings and plant biomass upon inoculation with rhizobacteria under drought stress conditions were observed in mustard, pearl millet and cluster bean (Bandeppa et al., 2015; Manjunatha et al., 2017; Rathi et al., 2018a). The last two decades have witnessed many reports on the utilization of such microbes for induction of tolerance against drought stress.
Kavamura et al., (2013), reported that plant growth promoting rhizobacteria (PGPR) obtained from extreme environmental conditions may protect plants from the harmful effects of drought stress and increases crop productivity in arid or semiarid areas. Hence, identification and development of eco-friendly strategies using microbes that can improve plant growth under water deficit stress are an immediate need in agricultural systems. Considering these facts in view, the present study was carried out to screen and identify the potential osmotolerant bacterial strains. The influence of these bacterial strains on germination of seeds and early stages of plant growth under osmotic stress condition were also studied.

\section{Materials and Methods}

\section{Growth and maintenance of rhizobacteria}

For the present study, bacteria isolated from mustard, cluster bean and pearl millet grown under drought conditions, available in the germplasm of Division of Microbiology, IARI, New Delhi were used. Table 1 has the list of rhizobacterial strains used in the study. Nutrient agar medium and slants and storage at $4{ }^{\circ} \mathrm{C}$ was used for the growth and maintenance of these bacterial cultures. Subculturing was done as and when needed.

\section{Screening of bacterial strains}

\section{Effect of osmotic stress on rhizobacterial growth}

Nutrient broth supplemented with 30 and 40 $\%$ PEG 6000 in culture tubes were used for the determination of the influence of osmotic stress on rhizobacterial growth. Inoculum of 2 $\%, 24 \mathrm{~h}$ old bacterial cultures were inoculated and incubated for $48 \mathrm{~h}$ at $28 \pm 2{ }^{\circ} \mathrm{C}$ on a shaker at $200 \mathrm{rpm}$. After $48 \mathrm{~h}$, turbidity of the cultures was measured as a determinant of 
bacterial growth using a spectrophotometer at $660 \mathrm{~nm}$.

\section{Effect on seed germination}

Mustard seeds of variety Pusa Karishma LES39 (Drought-susceptible) obtained from Division of Genetics, IARI, New Delhi was used for the experiment. Mustard seeds were surface sterilized with $0.1 \% \mathrm{HgCl}_{2}$ solution for $2 \mathrm{~min}$, then washed several times thoroughly with sterile water to remove traces of mercuric chloride. The seeds were inoculated with one day old cultures of bacterial strains for $60 \mathrm{~min}$. After inoculation the seeds were placed on petri plates containing $0.8 \%$ agar with $20 \%$ PEG 6000 as osmotic stress treatment and $0.8 \%$ agar as no stress condition. Uninoculated controls and replications were maintained for each treatment. The plates were incubated for germination $48 \mathrm{~h}$ at $25 \pm 2^{\circ} \mathrm{C}$. Observations such as seed germination percentage and fresh weight of seedlings were recorded after $48 \mathrm{~h}$ if germination to screen the potential plant growth promotion by rhizobacterial strains.

\section{Influence of osmotolerant bacteria on seed germination and plant growth}

Two plant growth promoting and osmotolerant bacterial isolates were selected and further analysed under in-vitro and invivo conditions for their potential in drought stress alleviation.

\section{Influence on germination of seeds and vigor}

Surface sterilized mustard seeds were inoculated with one day old cultures of MRD17 and MKS-6, placed on petri plates containing $0.8 \%$ agar as control and $0.8 \%$ agar with 20\% PEG 6000 as osmotic stress. The plates were incubated at $25 \pm 2^{\circ} \mathrm{C}$ for 72 $h$ and observations on seedling length and vigour index were taken to determine the influence of osmotolerant rhizobacteria on seed germination and seedling characteristics. Seedling vigour index $=$ SVI $=$ Germination percentage $\times$ Seedling length (Fig. 3).

\section{Influence on early stages of plant growth}

The study was conducted under both sterile and unsterile condition. Surface sterilized mustard seeds were inoculated with MRD-17 and MKS-6, and sown in four-inch pots containing $500 \mathrm{~g}$ soil. For maintaining sterile condition, experiment was conducted in sterile soil, by autoclaving the pots with soil at $120^{\circ} \mathrm{C}, 15 \mathrm{psi}$ for $4 \mathrm{~h}$ and by maintaining the moisture content using sterile water. Field capacity was maintained in control treatments and water deficit stress was imposed after 7 days of germination in stress treatments by maintaining $50 \%$ field capacity. Moisture level in pots was maintained by gravimetric method. Shoot and root dry weight were recorded at $15^{\text {th }}$ and $30^{\text {th }}$ days after sowing.

\section{Statistical analysis}

Data on screening of bacterial strains was subjected to one factor analysis and data generated on most of the other parameters was subjected to two factor analysis using OPSTAT statistical software. Duncan's multiple range test (DMRT) at $p<0.05$ was performed for comparison of treatment means.

\section{Results and Discussion}

Effect of osmotic stress induced by PEG 6000 on the growth of bacterial strains was observed (Table 2). Even though reduction in growth was observed under osmotic stress, all bacterial strains were observed to grow in 30 and $40 \%$ PEG 6000 concentration. In control treatment, MRD-17, NSRSSS-1, NAD-7 and MKS-6 recorded highest growth. Nearly 47- 
$69 \%$ reduction in growth was recorded due to the supplementation of media with $30 \%$ PEG 6000. Highest growth was recorded for NSRSSS- 1 followed by MRD-17 and MKS-6. Although, the strains were observed to grow in presence of $40 \%$ PEG 6000, growth was drastically reduced. Bacteria isolated from extreme environments are known to possess tolerance to those environments. As these bacterial strains were from drought stressed environment, all strains had tolerance to PEG 6000 induced osmotic stress. Malakar et al., (2014), also reported reduction in bacterial growth under PEG 6000 induced osmotic stress. Less reduction in growth under osmotic stress compared to control indicates its osmotolerance ability (Bandeppa et al., 2015; Manjunatha et al., 2017). Potential of these bacterial strains in improving the germination of mustard seeds (invitro) under osmotic stress condition were analysed (Table $3)$. Even though, inoculation with MRD-17, MMS-5, MKS-6 and MCL-1 recorded more than $90 \%$ seed germination at $48 \mathrm{~h}$, the treatments were found to be statistically on par. Inoculation with bacterial strains significantly improved the fresh weight of seedlings. Highest seedling fresh weight was observed in seedlings inoculated with MRD17 followed by MKS- 6 and MCL-1.

Table.1 Bacterial isolates used for the study

\begin{tabular}{|l|l|}
\hline Sl. No. & Bacterial isolates \\
\hline $\mathbf{1}$ & MRD-17 \\
\hline $\mathbf{2}$ & MMS-5 \\
\hline $\mathbf{3}$ & MKS-6 \\
\hline $\mathbf{4}$ & NAD-7 \\
\hline $\mathbf{5}$ & NSRSSS-1 \\
\hline $\mathbf{6}$ & MCL-1 \\
\hline $\mathbf{7}$ & MKS-1 \\
\hline
\end{tabular}

Table.2 Effect of osmotic stress on bacterial isolates growth

\begin{tabular}{|l|l|c|c|c|}
\hline Sl. No. & \multirow{2}{*}{ PGPB } & \multicolumn{3}{|c|}{ Growth obtained (in O.D. at 660 nm) $^{\mathbf{2}}$} \\
\cline { 3 - 5 } & & Control $^{\mathbf{2}}$ & $\mathbf{3 0}$ \% PEG 6000 & $\mathbf{4 0}$ \% PEG 6000 \\
\hline $\mathbf{1}$ & MRD-17 & 2.135 & 0.893 & 0.307 \\
\hline $\mathbf{2}$ & MMS-5 & 1.494 & 0.590 & 0.152 \\
\hline $\mathbf{3}$ & MKS-6 & 1.878 & 0.711 & 0.271 \\
\hline $\mathbf{4}$ & NAD-7 & 1.942 & 0.658 & 0.292 \\
\hline $\mathbf{5}$ & NSRSSS-1 & 2.120 & 1.103 & 0.353 \\
\hline $\mathbf{6}$ & MCL-1 & 1.496 & 0.466 & 0.111 \\
\hline $\mathbf{7}$ & MKS-1 & 1.402 & 0.430 & 0.065 \\
\hline SE $\mathbf{( m )} \mathbf{\pm}$ & & $\mathbf{0 . 0 8 4}$ & $\mathbf{0 . 0 4 7}$ & $\mathbf{0 . 0 2 1}$ \\
\hline $\mathbf{C D}$ @ 5\% & $\mathbf{0 . 2 5 7}$ & $\mathbf{0 . 1 4 4}$ & $\mathbf{0 . 0 6 3}$ \\
\hline
\end{tabular}

Values are means of three replications

${ }^{1}$ Observations at $48 \mathrm{~h}$ after incubation at $28 \pm 2^{\circ} \mathrm{C}$ in $200 \mathrm{rpm}$ orbital shaker.

${ }^{2}$ Nutrient broth was used for the growth of bacteria 
Table.3 Effect of bacterial inoculation and osmotic stress on seed germination

\begin{tabular}{|l|l|c|c|c|c|}
\hline \multirow{2}{*}{$\begin{array}{l}\text { Sl. } \\
\text { No }\end{array}$} & \multirow{2}{*}{ Treatments } & \multicolumn{2}{|c|}{ Control } & \multicolumn{2}{|c|}{ Osmotic stress } \\
\cline { 3 - 6 } & & $\begin{array}{c}\text { Germination } \\
\text { percentage }\end{array}$ & $\begin{array}{c}\text { Fresh weight } \\
\text { (mg) seedling }\end{array}$ & $\begin{array}{c}\text { Germination } \\
\text { percentage }\end{array}$ & $\begin{array}{c}\text { Fresh weight } \\
\text { (mg) seedling }\end{array}$ \\
\hline $\mathbf{1}$ & Uninoculated & 88.89 & 12.24 & 31.11 & 5.18 \\
\hline $\mathbf{2}$ & MRD-17 & 95.56 & 18.04 & 75.56 & 11.38 \\
\hline $\mathbf{3}$ & MMS-5 & 97.78 & 14.47 & 62.22 & 8.56 \\
\hline $\mathbf{4}$ & MKS-6 & 93.33 & 17.13 & 73.33 & 10.29 \\
\hline $\mathbf{5}$ & NAD-7 & 86.67 & 15.18 & 64.44 & 8.71 \\
\hline $\mathbf{6}$ & NSRSSS-1 & 86.67 & 14.64 & 55.56 & 7.36 \\
\hline $\mathbf{7}$ & MCL-1 & 95.56 & 16.02 & 51.11 & 6.89 \\
\hline $\mathbf{8}$ & MKS-1 & 88.89 & 13.98 & 53.33 & 7.64 \\
\hline SE (m) $\mathbf{\pm}$ & 4.158 & 1.075 & 4.303 & 0.949 \\
\hline CD @ 5\% & N/A & 3.251 & 13.011 & 2.870 \\
\hline
\end{tabular}

Values are means of three replications.

${ }^{1}$ Observations were taken at $48 \mathrm{~h}$ of germination

${ }^{2}$ Osmotic stress was induced by supplementing $0.8 \%$ agar added with 20\% PEG 6000

Table.4 Anova for various seedling characteristics as the effect of osmotolerant bacteria inoculation under control and osmotic stress condition

\begin{tabular}{|l|l|c|c|c|c|c|c|}
\hline Sl. & & \multicolumn{2}{|c|}{ Factor (A) } & \multicolumn{2}{c|}{ Factor (B) } & \multicolumn{2}{c|}{ Factor (A X B) } \\
\cline { 3 - 8 } No & Treatments & SE $(\mathrm{m}) \pm$ & CD @ 5\% & SE $(\mathrm{m}) \pm$ & CD @ 5\% & SE (m) \pm & CD @ 5\% \\
\hline $\mathbf{1}$ & Seedling length & 0.102 & 0.317 & 0.125 & 0.388 & 0.176 & 0.549 \\
\hline $\mathbf{2}$ & Seedling vigour & 12.101 & 37.699 & 14.820 & 46.171 & 20.959 & 65.296 \\
\hline
\end{tabular}

Table.5 Effect of inoculation with rhizobacteria and osmotic stress on early stages of plant growth under sterile condition

\begin{tabular}{|c|c|c|c|c|c|c|c|c|c|}
\hline \multirow{2}{*}{\multicolumn{2}{|c|}{ Treatments }} & \multicolumn{4}{|c|}{ Shoot dry weight $\left(\mathrm{mg} \mathrm{plant}^{-1}\right)$} & \multicolumn{4}{|c|}{ Root dry weight (mg plant $\left.{ }^{-1}\right)$} \\
\hline & & \multirow{2}{*}{\multicolumn{2}{|c|}{$\begin{array}{c}\text { 15 DAS } \\
11.33\end{array}$}} & \multirow{2}{*}{\multicolumn{2}{|c|}{$\begin{array}{c}\text { 30 DAS } \\
64.28\end{array}$}} & \multirow{2}{*}{\multicolumn{2}{|c|}{$\begin{array}{c}\text { 15 DAS } \\
6.97\end{array}$}} & \multirow{2}{*}{\multicolumn{2}{|c|}{$\begin{array}{c}\text { 30 DAS } \\
19.48\end{array}$}} \\
\hline \multirow{3}{*}{$\begin{array}{l}\text { Control (Field } \\
\text { capacity) }\end{array}$} & Uninoculated & & & & & & & & \\
\hline & MRD-17 & \multicolumn{2}{|c|}{17.96} & \multicolumn{2}{|c|}{170.41} & \multicolumn{2}{|c|}{25.59} & \multicolumn{2}{|c|}{49.31} \\
\hline & MKS-6 & \multicolumn{2}{|c|}{19.1} & \multicolumn{2}{|c|}{127.84} & \multicolumn{2}{|c|}{16.91} & \multicolumn{2}{|c|}{43.23} \\
\hline \multirow{3}{*}{$\begin{array}{l}\text { Water deficit } \\
\text { stress } \\
\text { (50\% Filed } \\
\text { capacty) }\end{array}$} & Uninoculated & \multicolumn{2}{|c|}{4.99} & \multicolumn{2}{|c|}{28.75} & \multicolumn{2}{|c|}{4.49} & \multicolumn{2}{|c|}{5.83} \\
\hline & MRD-17 & \multicolumn{2}{|c|}{11.01} & \multicolumn{2}{|c|}{87.26} & \multicolumn{2}{|c|}{8.06} & \multicolumn{2}{|c|}{22.2} \\
\hline & MKS-6 & \multicolumn{2}{|c|}{9} & \multicolumn{2}{|c|}{70.35} & \multicolumn{2}{|c|}{8.73} & \multicolumn{2}{|c|}{18.37} \\
\hline & & $\mathrm{SEm}+$ & $\begin{array}{c}\mathrm{CD} \text { at } \\
5 \%\end{array}$ & $\mathrm{SEm}+$ & $\begin{array}{l}\mathrm{CD} \text { at } \\
5 \%\end{array}$ & $\mathrm{SEm} \pm$ & $\begin{array}{l}\mathrm{CD} \text { at } \\
5 \%\end{array}$ & $\mathrm{SEm} \pm$ & $\begin{array}{c}\mathrm{CD} \text { at } \\
5 \%\end{array}$ \\
\hline \multicolumn{2}{|c|}{ Factor (Water deficit Stress) } & 0.220 & 0.685 & 1.320 & 4.112 & 0.379 & 1.181 & 0.566 & 1.764 \\
\hline \multicolumn{2}{|c|}{ Factor (Inoculation) } & 0.269 & 0.839 & 1.617 & 5.037 & 0.464 & 1.446 & 0.693 & 2.160 \\
\hline \multicolumn{2}{|c|}{$\begin{array}{l}\text { Factor (water deficit stress } \mathbf{X} \\
\text { Inoculation) }\end{array}$} & 0.381 & 1.187 & 2.286 & 7.123 & 0.656 & 2.045 & 0.981 & 3.055 \\
\hline
\end{tabular}

Values are means of three replications 
Table.6 Effect of inoculation with rhizobacteria and osmotic stress on early stages of plant growth under unsterile condition

\begin{tabular}{|c|c|c|c|c|c|c|c|c|c|}
\hline \multirow{2}{*}{\multicolumn{2}{|c|}{ Treatments }} & \multicolumn{4}{|c|}{ Shoot dry weight $\left(\mathrm{mg} \mathrm{plant}^{-1}\right)$} & \multicolumn{4}{|c|}{ Root dry weight (mg plant $\left.{ }^{-1}\right)$} \\
\hline & & \multirow{2}{*}{\multicolumn{2}{|c|}{$\begin{array}{c}\text { 15 DAS } \\
6.37\end{array}$}} & \multirow{2}{*}{\multicolumn{2}{|c|}{$\begin{array}{c}\text { 30 DAS } \\
43.7\end{array}$}} & \multirow{2}{*}{\multicolumn{2}{|c|}{$\begin{array}{c}\text { 15 DAS } \\
4.54\end{array}$}} & \multirow{2}{*}{\multicolumn{2}{|c|}{$\begin{array}{c}30 \text { DAS } \\
8.06\end{array}$}} \\
\hline \multirow{3}{*}{$\begin{array}{l}\text { Control (Field } \\
\text { capacity) }\end{array}$} & Uninoculated & & & & & & & & \\
\hline & MRD-17 & \multicolumn{2}{|c|}{11.38} & \multicolumn{2}{|c|}{63.23} & \multicolumn{2}{|c|}{9.06} & \multicolumn{2}{|c|}{15.12} \\
\hline & MKS-6 & \multicolumn{2}{|c|}{9.31} & \multicolumn{2}{|c|}{57.13} & \multicolumn{2}{|c|}{8.35} & \multicolumn{2}{|c|}{14.36} \\
\hline \multirow{3}{*}{$\begin{array}{l}\text { Water deficit stress } \\
\text { (50\% Field } \\
\text { capacity) }\end{array}$} & Uninoculated & \multicolumn{2}{|c|}{4.88} & \multicolumn{2}{|c|}{30.95} & \multicolumn{2}{|c|}{3.28} & \multicolumn{2}{|c|}{6.55} \\
\hline & MRD-17 & \multicolumn{2}{|c|}{8.75} & \multicolumn{2}{|c|}{51.72} & \multicolumn{2}{|c|}{5.1} & \multicolumn{2}{|c|}{11.68} \\
\hline & MKS-6 & \multicolumn{2}{|c|}{7.88} & \multicolumn{2}{|c|}{48.16} & \multicolumn{2}{|c|}{5.04} & \multicolumn{2}{|c|}{13.39} \\
\hline & & $\mathrm{SEm} \pm$ & $\begin{array}{c}\mathrm{CD} \text { at } \\
5 \%\end{array}$ & $\mathrm{SEm} \pm$ & $\begin{array}{c}\mathrm{CD} \text { at } \\
5 \%\end{array}$ & $\mathrm{SEm} \pm$ & $\begin{array}{l}\mathrm{CD} \text { at } \\
5 \%\end{array}$ & $\mathrm{SEm} \pm$ & $\begin{array}{c}\mathrm{CD} \text { at } \\
5 \%\end{array}$ \\
\hline \multicolumn{2}{|c|}{ Factor (Water deficit Stress) } & 0.130 & 0.404 & 0.481 & 1.500 & 0.106 & 0.331 & 0.081 & 0.253 \\
\hline \multicolumn{2}{|c|}{ Factor (Inoculation) } & 0.159 & 0.494 & 0.590 & 1.837 & 0.130 & 0.405 & 0.099 & 0.310 \\
\hline \multicolumn{2}{|c|}{$\begin{array}{l}\text { Factor (water deficit stress } \mathrm{X} \\
\text { Inoculation) }\end{array}$} & 0.224 & 0.699 & 0.834 & N/A & 0.184 & 0.573 & 0.141 & 0.438 \\
\hline \multicolumn{2}{|c|}{$\begin{array}{l}\text { Values are means of three } \\
\text { replications. }\end{array}$} & & & & & & & & \\
\hline
\end{tabular}

Fig.1 Effect of selected bacterial isolates on germination percentage at 24, 48 and $72 \mathrm{~h}$ under control and osmotic stress condition

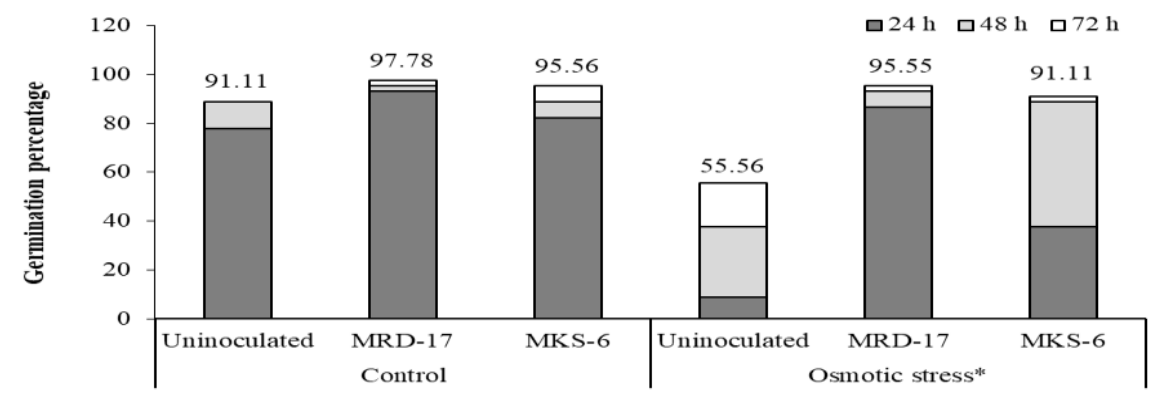

Values are the means of 3 replications and numbers in end of the columns indicate the germination percentage of each treatment at 72 h. *Osmotic stress induced by 20\% PEG 6000

Fig.2 Effect of selected bacterial isolates on fresh weight of seedlings under osmotic stress condition at 24,48 and $72 \mathrm{~h}$ of germination

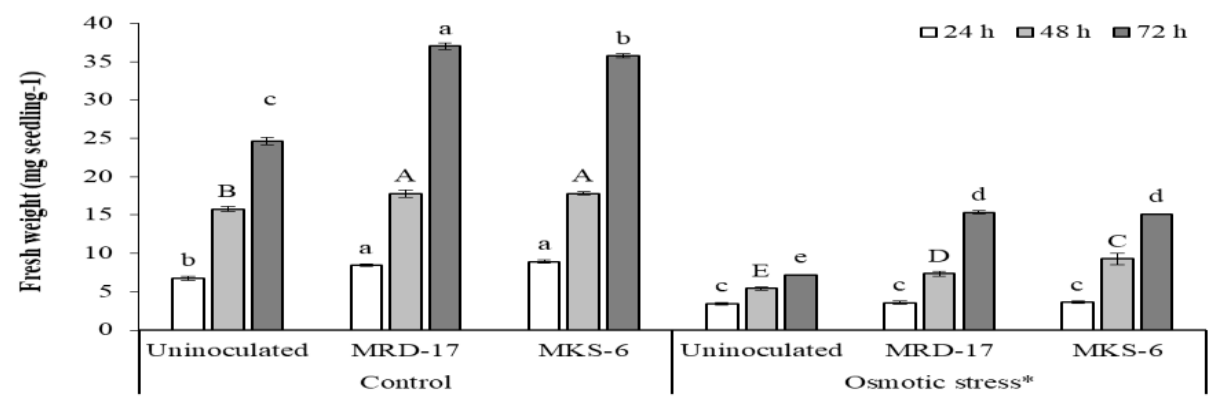

Values are means of three replications. Error bars represent SE. Data followed by different letters are significantly different at the specified time at $\mathrm{P}<0.05$. *Osmotic stress induced by $20 \%$ PEG 6000 
Fig.3 Effect of inoculation with the osmotolerant bacterial isolates on the length of seedlings at $72 \mathrm{~h}$ under osmotic stress condition

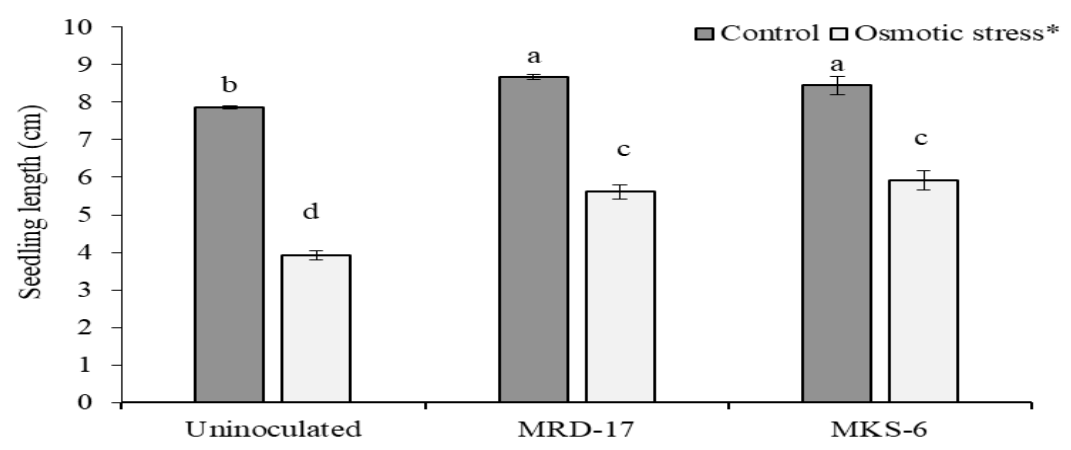

Values are means of three set of 15 replications. Error bars represent SE. Data followed by different letters are significantly different at $\mathrm{P}<0.05$. *Osmotic stress induced by $20 \%$ PEG 6000

Fig.4 Effect of inoculation with the osmotolerant bacterial isolates on the length of seedlings at $72 \mathrm{~h}$ under osmotic stress condition

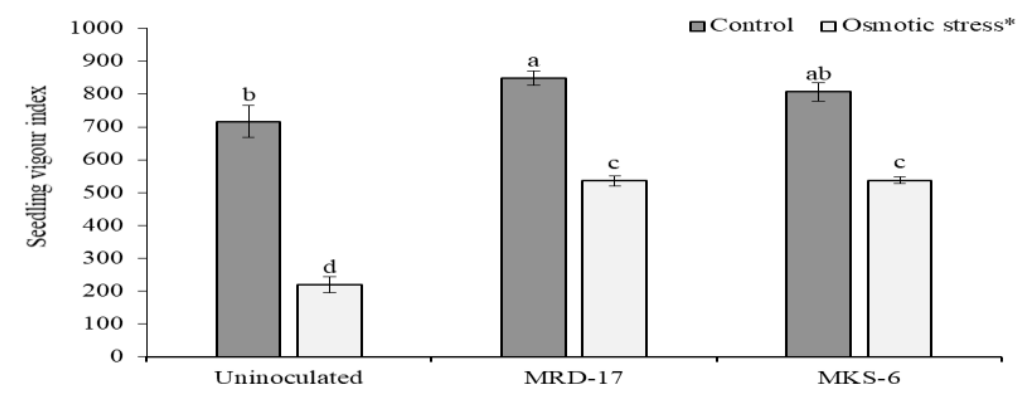

Values are means of three replications. Error bars represent SE. Data followed by different letters are significantly different at $\mathrm{P}<0.05$. *Osmotic stress induced by $20 \%$ PEG 6000

Osmotic stress drastically reduced the percent germination and fresh weight of seedlings. Inoculation with rhizobacteria enhanced the seed germination percentage (1.65 to 2.42 fold) and seedling fresh weight (1.33 to 2.20fold) under osmotic stress condition. Highest enhancements were observed in seedlings inoculated with MRD-17 followed by MKS6. Similar observations were also recorded by Delshadi et al., (2017). Germination rate and vigour was improved in Onobrychis sativa upon inoculation with Azotobacter and Pseudomonas but there was no effect on germination percentage. In our study, even though NSRSSS-1 was more osmotolerant, its seed germination promoting potential was less compared to MRD-17 and MKS-6. Hence, bacterial strains MKS-6 and MRD-17 were selected for further experiments.

Selected bacterial strains MRD-17 and MKS6 were further tested for their ability to enhance seedling vigour in petri plates (invitro) and plant growth (invivo) under water deficit stress condition under pot experiment. Observations were subjected to two-way anova and analysed (Table 4). Inoculation with MRD-17 and MKS-6 led to enhancement in seedling length (Fig 1) under control (one-fold) as well as osmotic stress condition (1.4 to 1.5-fold). Even though the values of seedlings inoculated with both the osmotolerant bacteria were statistically on par, MRD-17 recorded highest seedling 
length under control condition and MKS-6 recorded under osmotic stress condition. Significant enhancement in seedling vigour index was observed in seedlings inoculated with these osmotolerant bacteria (Fig 2). Nearly one-fold increase under control and 2.5 -fold increase under osmotic stress condition was observed in seedling vigour index due to inoculation.

Many reports available on the effect of inoculation with rhizobacteria on the improvement of seed germination under osmotic stress condition in many crops. Seed priming with plant growth-promoting microbial inoculants significantly promoted the seed germination and fresh weight under moisture stress (Kalita et al., 2015). Nezarat and Gholami (2009) also observed similar significant enhancement in seed germination and seedling vigour of maize due to the inoculation with PGPR cultures Pseudomonas putida, $P$. fluorescence, Azospirillum lipoferum and $A$. brasiliense. Inoculation with Pseudomonas aeruginosa strain BHUPSB02, Bacillus subtilis strain BHUPSB13, P. putida strain BHUPSB04, Bacillus boronophilus strain BHUPSB19 and Paenibacillus polymyxa strain BHUPSB17 were reported to increase the length and dry weight of 21 days old seedlings, even though there was no significant improvement in germination percentage (Yadav et al., 2010).

Potential of MKS-6 and MRD-17 in the alleviation of water deficit stress of mustard plants were tested in pot experiments under sterile and unsterile condition. Under both sterile and unsterile conditions, significant increase in shoot and root dry weight was observed due to inoculation with MRD-17 followed by MKS-6 under control and osmotic stress condition. Zhu et al., (2014) also confirmed the influence of plant growth promoting rhizobacteria in increasing the shoot and root dry weight, shoot morphology, biomass, water use efficiency and photosynthetic rate in wheat under water deficit stress condition. Significant enhancement in plant height, biomass and relative water content was observed under drought stress conditions in jujube plants inoculated with Pseudomonas lini and Serratia plymuthica (Zhang et al., 2020).

Influence of inoculation was clearly observed in sterile condition compared to unsterile condition. Under sterile condition (Table 5), nearly $36-72 \%$ increase at 15 DAS and 50$62 \%$ increase at 30 DAS was observed in shoot and root dry weight due to inoculation under control condition. Similarly, inoculation led to $45-55 \%$ increase at 15 DAS and $59-73 \%$ increase at 30 DAS in shoot and root dry weight under drought stress condition. Under unsterile condition (Table 6), 24-44\% enhancement in shoot and 44-50\% increase in root dry weight were observed in seedlings inoculated with MRD-17 and MKS6 during $15^{\text {th }}$ and 30 DAS in control condition. Inoculation with osmotolerant bacterial strains MRD-17 and MKS-6 led to significant enhancement up to $36-44 \%$ in shoot and $35-51 \%$ in root dry weight under water deficit stress condition. In unsterile soil, the positive impact on plant growth was observed to be less prominent than sterile soil. It may be due to the competition given by native soil microbes to bioinoculants. Oats inoculated with plant growth promoting Bacillus strains also reported similar results (Hashmi et al., 2019). Higher benefits of inoculation in terms of root biomass and shoot biomass were reduced in wheat and Amaranthus under sterile condition as compared to unsterile soil (Nair et al., 2007; Mahmood et al., 2014).

Rhizobacteria are known to improve water use efficiency of inoculated plants under abiotic stress conditions (Mayak et al., 2004). The present investigation confirmed the effect 
of bacterial strains MKS-6 and MRD-17 in imparting drought stress tolerance in mustard. These strains have the potential to be developed into bio inoculants for imparting drought stress tolerance to mustard.

\section{References}

Bandeppa, Paul, S., Kandpal, B.K. (2015). Evaluation of osmotolerant rhizobacteria for alleviation of water deficit stress in mustard. Green Farming, 3: 590-593.

Chauhan, J. S., Singh, K. H., Singh, V. V. and Kumar, S. (2011). Hundred years of rapeseed-mustard breeding in India: accomplishments and future strategies. Indian Journal of Agricultural Sciences, 81: 1093-1109.

Delshadi, S., Ebrahimi, M. and Shirmohammadi, E. (2017). Influence of plant-growth-promoting bacteria on germination, growth and nutrients' uptake of Onobrychis sativa L. under drought stress. Journal of Plant Interactions, 12: 200-208.

Fahad, S., Hussain, S., Bano, A., Saud, S., Hassan, S., Shan, D., Khan, F. A., Khan, F., Chen, Y., Wu, C., Tabassum, M. A., Chun, M. X., Afzal, M., Jan, A., Jan, M. T. and Huang, J. (2014). Potential role of phytohormones and plant growthpromoting rhizobacteria in abiotic stresses: consequences for changing environment. Environmental Science and Pollution Research, 22: 4907-4921.

Ghobadi, M., Bakhshandeh, M., Fathi, G., Gharineh, M. H., Alamisaeed, K., Naderi, A. and Ghobadi, V. (2006). Short and long periods of water stress during different growth stages of canola (Brassica napus L.). Effect on yield, yield components, seed oil and protein contents. Agronomy Journal, 5: 336-341.

Hashmi, I., Paul, C., Al-Dourobi, A., Sandoz, F., Deschamps, P., Junier, T., Junier, P. and Bindschedler, S. (2019). Comparison of the plant growth-promotion performance of a consortium of Bacilli inoculated as endospores or as vegetative cells. FEMS Microbiology Ecology, 95: 147.

Jensen, C. R., Mogensen, V.O., Mortensen, G., Fieldsend, J. K., Milford, F. J., Andersen M. N. and Thage, J. H. (1996). Seed glucosinolate, oil and protein contents of fieldgrown rape (Brassica napus L.) affected by soil drying and evaporative demand. Field Crops Research, 47: 93105.

Kalita, M., Bharadwaz, M., Dey, T., Gogoi, K., Dowarah, P., Unni, B. G. (2015). Developing novel bacterial based bioformulation having PGPR properties for enhanced production of agricultural crops. Indian Journal of Experimental Biology, 53: 56-60.

Kavamura, V. N., Santos, S. N., da Silva, J. L., Parma, M. M., Ávila, L. A., Visconti, A., Zucchi, T.D., Taketani, R.G., Andreote, F.D. and de Melo, I. S. (2013). Screening of Brazilian cacti rhizobacteria for plant growth promotion under drought. Microbiological research, 168: 183-191.

Kim, W., Iizumi, T. and Nishimori, M. (2019). Global patterns of crop production losses associated with droughts from 1983 to 2009. Journal of Applied Meteorology and Climatology, 58: 1233-1244. https://doi.org/10.1175/JAMC-D-180174.1

Mahmood, T., Mehnaz, S., Fleischmann, F., Ali, R., Hashmi, Z. H. and Iqbal, Z. (2014). Soil sterilization effects on root growth and formation of rhizosheaths in wheat seedlings. Pedobiologia, 57:123130.

https://doi.org/10.1016/j.pedobi.2013.12. 005

Malakar, P., Singh, V. K., Karmakar, R. and Venkatesh, K. V. (2014). Effect on $\beta$ galactosidase synthesis and burden on growth of osmotic stress in Escherichia coli. Springer Plus, 3: 748.

Manjunatha, B.S., A.D. Asha, N. Nivetha, Bandeppa, Govindasamy, V., Rathi, M. S. and Paul, S. (2017). Evaluation of endophytic bacteria for their influence on 
plant growth and seed germination under water stress conditions. International Journal of Current Microbiology and Applied Sciences, 6: 4061-4067. https://doi.org/10.20546/ijcmas.2017.611. 475

Mayak, S., Tirosh, T. and Glick, B. R. (2004). Plant growth-promoting bacteria confer resistance in tomato plants to salt stress. Plant physiology and Biochemistry, 42: 565-572.

Meena, K. K., Sorty, A. M., Bitla, U. M., Choudhary, K., Gupta, P., Pareek, A., Singh, D.P., Prabha, R., Sahu, P.K., Gupta, V.K. and Singh, H. B. (2017). Abiotic stress responses and microbemediated mitigation in plants: the omics strategies. Frontiers in plant science, 8: 172.

Nair, C. B., Anith, K. N. and Sreekumar, J. (2007). Mitigation of growth retardation effect of plant defense activator, acibenzolar-S-methyl, in amaranthus plants by plant growth-promoting rhizobacteria. World Journal of Microbiology and Biotechnology, 23: 1183-1187. https://doi.org/10.1007/s11274-006-9333Z

Nezarat, S. and Gholami, A. (2009). Screening plant growth promoting rhizobacteria for improving seed germination, seedling growth and yield of maize. Pakistan journal of biological sciences, 12: 26-32.

Rathi, M. S., Paul, S., Manjunatha, B. S., Kumar, V. and Varma, A. (2018). Isolation and screening of osmotolerant endophytic bacteria from succulent and non-succulent drought tolerant plants for water stress alleviation in cluster bean (Cyamopsis tetragonoloba). Vegetos, 31: 57-66. https://doi.org/10.5958/22294473.2018.00105.2

Yadav, J., Verma, J. P. and Tiwari, K. N. (2010). Effect of plant growth promoting rhizobacteria on seed germination and plant growth chickpea (Cicer arietinum L.) under in vitro conditions. In Biological Forum, 2: 15-18.

Zhang, M., Yang, L., Hao, R., Bai, X., Wang, Y. and $\mathrm{Yu}, \mathrm{X}$. (2020). Drought-tolerant plant growth-promoting rhizobacteria isolated from jujube (Ziziphus jujuba) and their potential to enhance drought tolerance. Plant and Soil, 452: 423-440.

Zhu, Y., Wang, Z., Wang, J., Wang, Z. and Zhou, J. (2014). Plant growth-promoting rhizobacteria improve shoot morphology and photosynthesis in dryland spring wheat. WIT Trans Built Environ, 145: 343-350.

\section{How to cite this article:}

Nivetha, N., A. Kiruthika, Arambam Devi Asha, A. K. Lavanya, K. V. Vikram, B. S. Manjunatha and Sangeeta Paul. 2020. Osmotolerant Rhizobacteria Improve Seedling Vigour and Plant Growth of Mustard under Water Scarcity. Int.J.Curr.Microbiol.App.Sci. 9(12): 19281937. doi: https://doi.org/10.20546/ijcmas.2020.912.229 